The authors examine the college conditions that contribute to character development, using data from the

National Survey of Student Engagement (NSSE).

\title{
College and Character: Insights from the National Survey of Student Engagement
}

\author{
George D. Kuh, Paul D. Umbach
}

Character is variously defined. At one level of abstraction, most would agree that character is a window into personality, a constellation of attitudes, values, ethical considerations, and behavioral patterns that represent what people believe and value, how they think, and what they do. When we say someone has "character," we mean that one exhibits admirable traits in both intellectual and behavioral dimensions of public and private life and acts with integrity in that behavior is congruent with values and beliefs. People of "good" character, then, work toward the public good, with integrity and personal responsibility that reflect their examined understanding of their ethical responsibility to self and the larger community.

Developing character was a primary goal of undergraduate education in the colonial colleges (Rudolph, 1990). The collegiate experience was intended to shape students' attitudes and values as much as to stretch their intellect and expand their knowledge of the world. Indeed, the initial wave of American colleges was founded by denominational groups in no small part to preserve an important facet of character: their religious heritage, beliefs, and values. As higher education expanded to accommodate a growing number of participants, the new institutions that emerged introduced other priorities. Existing colleges became more secular in their mission, philosophy, and curricular orientation. Thus the emphasis that colleges placed on character development declined commensurately, except at those institutions that retained more than a titular connection with their sponsoring denomination (Horowitz, 1987). 
Even as American higher education became more secular in orientation and practice, most institutions continued to include among their educational purposes one or more that underscored the importance of providing students with the opportunity to discover, refine, and test their character. Within the past decade, there has been a resurgence of interest in intentionally promoting civic engagement during college, stemming from several factors. Among the most pronounced are the national scandals and public embarrassments that began with Watergate and continued through Enron, the Catholic Church, and wrongdoings by Olympic athletes and organizers. These enduring, prickly events have left an ugly mark on the American psyche and are unpleasant reminders of what can happen when the bedrock of individual and corporate values and ethical systems are left unattended and atrophy.

Though some argue that the values and ethical systems of individual students are pretty well set before they come to college, the literature suggests that the college experience can at the least accentuate a student's values development trajectory (Astin, 1993; Feldman and Newcomb, 1969; Pascarella and Terenzini, 1991). That is, college can further support and channel maturational processes under way to crystallize and integrate the attitudinal and values dimension of a student's identity (Chickering and Reisser, 1993). In a small fraction of cases, perhaps no more than 10 percent (Clark and others, 1972), college may have a transforming effect, resulting in substantial reorganization of one's personality. The impact of college on values development is mediated significantly by peer interaction (Astin, 1977; Astin, Sax, and Avalos, 1999; Kuh, 1993, 1995; Pascarella and Terenzini, 1991). Moreover, college is likely to have a shaping influence on values development of students who are actively involved in both academic and out-of-class activities. Thus it stands to reason that character development is enhanced by taking part in a variety of educationally purposeful activities.

If college attendance is to affect, even marginally, the character of its students, what conditions must be present? Which college experiences contribute to character development? Most of the theorizing and empirical studies about character development during the college years, as we have defined it, are small $n$ or single-institution studies (for example, Baxter Magolda, 2001; Heath, 1968; Parks, 2000). Aside from a few classic multiple institution studies (see Astin, 1977, 1993; Jacob, 1957; Sanford, 1962), there is little information to estimate the extent to which the undergraduate experience has a positive, shaping influence on the character of contemporary college students across a large number of institutions. Moreover, most of the studies addressing character building during the undergraduate years focus on character-related attitudes and values; few studies emphasize the behavior that shapes or is associated with character development. Yet how students behave-what they do during college-is essential for knowing whether institutions are providing the type of experience 
inside and outside the classroom that has a positive shaping influence on character. In addition, such evidence is arguably a precursor of what one might expect of college graduates in later life.

\section{Purpose and Overview}

This chapter offers some insight into the activities and collegiate experiences that are associated with character development. Our data come from the National Survey of Student Engagement (NSSE), an annual survey of college students that focuses on the amount of time and energy students devote to educationally purposeful activities. The NSSE national database allows us to answer two questions relevant to character development: (1) What experiences during college are related to student self-reports of their character development? (2) Do some institutions and institutional types differentially affect character development? That is, do students at some types of institution, such as denominational colleges, report greater gains in the areas that contribute to character development?

First, we describe the nature of the information and analytical approaches we employed to answer these two questions. We then summarize major findings from the analysis. We close with implications and ideas for additional research that might yield insight into character development as part of the undergraduate experience.

\section{Insights from NSSE about Character Development During College}

The National Survey of Student Engagement is an annual survey of first-year and senior students that measures the degree to which students participate in educational practices that prior research shows are linked to valued outcomes of college (Chickering and Gamson, 1987; Kuh, 2001). For all practical purposes, the participating institutions are representative of the four-year college population by Carnegie type, sector, and region of the county, and in other dimensions.

The NSSE survey instrument, The College Student Report, asks students about their experiences in four areas: (1) the amount of time and effort devoted to various in-class and out-of-class activities, including reading and writing, and the frequency with which students participate in class discussions, make class presentations, work with peers on problem solving, and interact with faculty members; (2) participation in enriching educational activities (study abroad, internships, and so on); (3) gains in personal and educational development; and (4) perceptions of the college environment, including overall satisfaction with college and quality of academic advising. As Sweet Briar College president Elisabeth Muhlenfeld said, the NSSE items represent "an effort to get at the habits of mind." 
The survey relies on student self-reports. A fair amount of research (Baird, 1976; Berdie, 1971; Pace, 1985; Pike, 1995; Pohlmann, 1974) has shown that self-reports are likely to be valid if (1) the information requested is known to the respondents; (2) the questions are phrased clearly and unambiguously; (3) the questions refer to recent activities; (4) the respondents think the questions merit a serious and thoughtful response; and (5) answering the questions does not threaten, embarrass, or violate the privacy of the respondent or encourage the respondent to respond in socially desirable ways (Kuh and $\mathrm{Hu}, 2001$ ). The NSSE survey was designed to satisfy all of these conditions. Self-reported information is particularly relevant for measuring aspects of the college experience, such as character development, that cannot be easily assessed through other means. Moreover, the absence of widely used psychometrically sound measures of character development makes it difficult to assess the construct without incorporating student self-reports.

The sample used in this study is composed of 49,692 seniors who completed the NSSE survey in 2002 and 2003 from 568 four-year colleges and universities. Only seniors who started college at the institution from which they were about to graduate were included in the analysis because they had the most exposure to that institution. Other research shows that transfer students differ systematically in their engagement from their counterparts who start and persist to graduation at the same college or university (Kuh, 2003; National Survey of Student Engagement, 2002). For this reason, we excluded students who had transferred; this simplifies interpretation of findings and allows us to be more confident about our conclusions concerning differences by institutional type.

\section{Data Analysis}

The independent variables were various measures of student engagement and perceptions of the campus. Student engagement was represented by three scales: (1) academic challenge, (2) active and collaborative learning, and (3) student-faculty interaction. The campus environment measure was made up of two subscales-interpersonal support and support for learning-as well as an overall satisfaction-with-college scale. We also used scales made up of subsets of items to reflect diversity-related activities and integrative learning experiences. Other studies (Antonio, 2001; Chang, 1999; Gurin, 1999; Milem and Hakuta, 2000; Umbach and Kuh, 2003) show that experiences with diversity have a positive effect on a variety of outcomes. Integration is a form of deep learning that requires acquisition of knowledge, skills, and competencies across a variety of academic and social activities into a meaningful whole. Items contributing to the integration scale include such activities as incorporating ideas from various sources into a paper, making use of diverse perspectives in class discussions or writing projects, and putting together ideas and concepts from different courses 
(National Survey of Student Engagement, 2003; Pike and Kuh, forthcoming; Pike, Kuh, and Gonyea, 2003).

To represent the dependent variable, character development, we selected twelve items from the self-reported gains section on the NSSE survey that reflect four related dimensions of character development. The question posed to students is, "To what extent has your experience at this institution contributed to your knowledge, skills and personal development in the following areas?" These are the four dimensions of character development and their contributing items:

1. Knowledge of self (three items):

Understanding self

Understanding people of other racial and ethnic backgrounds

Working effectively with others

2. Ethical development and problem solving (two items):

Developing a personal code of ethics

Solving complex real-world problems

3. Civic responsibility (two items):

Voting in local, state, and national elections

Contributing to the welfare of one's community

4. General knowledge (five items):

Acquiring a broad, general education

Learning effectively on one's own

Writing clearly and effectively

Speaking clearly and effectively

Thinking critically and analytically

Responses are scored on a four-point scale representing the amount of progress or gains for a student during college in each respective area, ranging from "very little" to "very much."

The data were analyzed in three stages. First, we used descriptive statistics to construct a profile of the dimensions of character development as they are represented on the NSSE survey. Second, because of the nested nature of the data and the intent to estimate institutional effects (Raudenbush and Bryk, 2002), we used hierarchical linear modeling (HLM) to explore student and institutional characteristics. Table 4.1 presents the descriptive statistics for the independent variables that relate to self-reported gains in character development. Because students at level one are nested within colleges at level two, HLM allows us to partition the variance between what can be attributed to colleges and what can be attributed to students.

At the student level, we include gender, age, race, student major, participation in Greek-letter organizations, grades, and full-time enrollment in our models. At the institutional level, we created dummy coded variables for the five Carnegie types: doctoral/research-extensive, doctoral/researchintensive, master's I and II, baccalaureate liberal arts, and baccalaureate 
Table 4.1. Descriptive Statistics of Independent Variables Included in Models

\begin{tabular}{lcccc}
\hline & Mean & Std. Dev. & Min. & Max. \\
\hline Independent Variables, Level 1 & & & & \\
Gender & 0.65 & 0.48 & 0.00 & 1.00 \\
Age & 0.00 & 1.00 & -1.48 & 12.93 \\
African American & 0.06 & 0.23 & 0 & 1 \\
Native American & 0.00 & 0.06 & 0 & 1 \\
Asian Pacific American & 0.05 & 0.22 & 0 & 1 \\
Latino & 0.03 & 0.18 & 0 & 1 \\
Other minority & 0.01 & 0.07 & 0 & 1 \\
Major-humanities & 0.15 & 0.36 & 0 & 1 \\
Major-math and science & 0.21 & 0.41 & 0 & 1 \\
Major-professional & 0.29 & 0.45 & 0 & 1 \\
Major-social sciences (omitted category) & 0.17 & 0.38 & 0 & 1 \\
Major-other & 0.19 & 0.39 & 0 & 1 \\
Greek & 0.17 & 0.38 & 0 & 1 \\
Grades & 0.00 & 1.00 & -2.79 & 1.31 \\
Full-time & 0.90 & 0.30 & 0 & 1 \\
Independent Variables, Level 2 & & & & \\
Doctoral/Research-Extensive & 0.12 & 0.32 & 0 & 1 \\
Doctoral/Research-Intensive & 0.09 & 0.28 & 0 & 1 \\
Master's I and II & 0.42 & 0.49 & 0 & 1 \\
Baccalaureate-liberal arts & 0.18 & 0.38 & 0 & 1 \\
Baccalaureate-general & 0.14 & 0.35 & 0 & 1 \\
Urban & 0.53 & 0.50 & 0 & 1 \\
Suburban & 0.24 & 0.42 & 0 & 1 \\
Town/rural & 0.23 & 0.42 & 0 & 1 \\
Private & 0.57 & 0.49 & 0 & 1 \\
Undergraduate head count & 0 & 1 & -0.86 & 4.93 \\
Selectivity (Barron's, 2002) & 0 & 1 & -2.1 & 2.55 \\
Religiously affiliated & 0.35 & 0.48 & 0 & 1 \\
\hline
\end{tabular}

general (McCormick, 2001). To determine whether character development of students varied with type of institution, baccalaureate liberal arts colleges were designated as the omitted group because as a set of schools they had the highest overall mean score on the aggregated character development measures (Figure 4.1). In addition, a sizeable percentage of baccalaureate liberal arts colleges still have strong ties with their founding denomination and claim to place a significant emphasis on character-related matters both in the curriculum and in out-of-class activities, such as offering daily chapel and community service. Therefore we included a religious affiliation variable at level two. Additionally, we examined sector (public, private), urbanicity (urban, suburban, small town or rural), size (total undergraduate headcount), and a measure of selectivity (derived from the 2002 Barron's College Guide).

It is common to build hierarchical linear models in stages. In the first stage of model building, we create the within (or the student-level) model 


\section{Figure 4.1. Self-Reported Gains in Character Development Score Among NSSE 2002-03 Seniors}

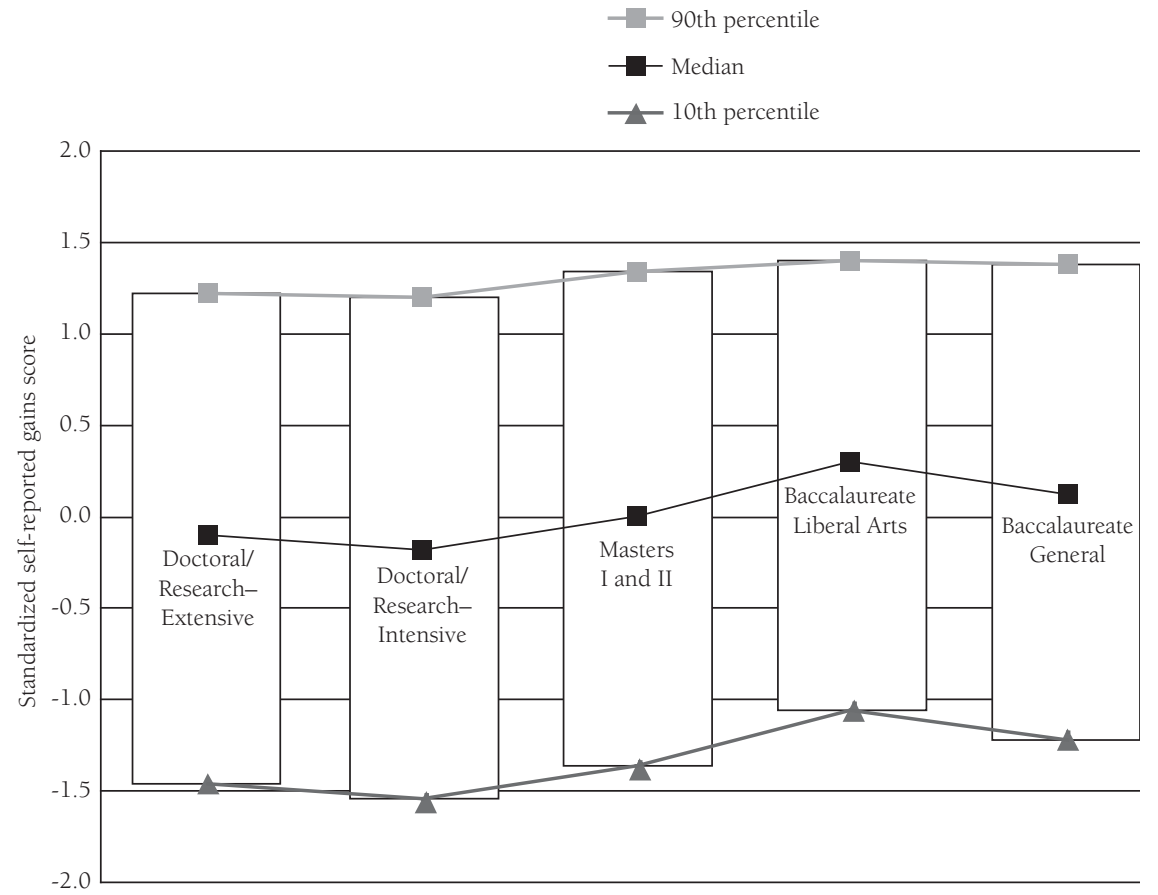

allowing the intercept to vary, thereby partitioning the variance that can be attributed to the institution. In the second stage, we build our full model by including level two predictors in our model. Because many of our level two predictors are highly correlated, we included each measure individually in our level two models.

In the third and final stage of the analysis, we built a series of hierarchical linear models to explore the relationships between character development and student engagement in educationally purposeful activities. We also examine the impact of perception of the campus environment and satisfaction on character development.

Because the number of students used in these analyses is large, it is important not only to examine statistical significance but also to understand the magnitude of difference. To understand substantive differences between students' character development scores for baccalaureate liberal arts colleges and other types of institutions, we calculated effect sizes (Rosenthal and Rosnow, 1991). The effect size is the proportion of a standard deviation change in the dependent variable as a result of a one-unit change in a dependent variable. We standardized all of the continuous independent and dependent measures in the models, so the unstandardized coefficients 
represent effect sizes. The larger the effect size, the more likely the difference between groups or institutional types reflects performance that warrants serious discussion and perhaps intervention. Following the suggestion of Rosenthal and Rosnow (1991), we considered an effect size of .10 or less to reflect a trivial difference, between .10 and .30 to be small, between .30 and .50 moderate, and greater than .50 large.

\section{How Does Student Engagement Shape Character?}

Our descriptive analyses show that students at baccalaureate liberal arts colleges report greater gains in character development than students at other types of colleges (Figure 4.1). Students at doctoral institutions report the lowest gains in character development during college.

Among the activities likely to contribute to character development are doing community service or working on a project in the community that is related to a course, volunteerism, the frequency with which students are exposed to diversity in the classroom, talking with students from other races and ethnicities, or having conversations with students who have different political and social views. Among the students who are more likely to experience diversity (and who may well report greater gains in character development) are students of color (contrasted with white students), traditional-aged students (contrasted with older students), women, and first-year students.

More than 60 percent participated in a community project during college (Figure 4.2), and most seniors (90+ percent) report encountering diverse perspectives in their classes. These experiences likely challenge students to develop novel or new ways of thinking and approaching issues, consistent with the challenge-and-support principle introduced by Nevitt Sanford (1962) and subsequently elaborated by others. Even so, about 15 percent of all seniors seem to get through the last year of college without having a serious conversation with a fellow student from another race and ethnicity. In part, this may be because of the self-segregation that occurs once a student leaves a campus residence hall and moves off campus. At the same time, the vast majority of students-about 82 percent-indicate that their college experience contributed substantially ("very much" or "quite a bit") to their ability to work effectively with others (Figure 4.3). Similarly, about 60 percent think college contributed substantially to their developing a systematic code of ethics. Especially troubling and disappointing is that more than half of all seniors say that their college experience had very little or an insignificant effect on the likelihood that they would vote in a local or national election (Figure 4.3).

\section{Institutional “Averages" Don't Tell the Whole Character Development Story}

One consistent, mildly provocative finding from the NSSE project is that the variance within an institution on any given measure is often greater than the variance between institutions including types of institutions. Figure 4.4 
Figure 4.2. All NSSE 2002-03 Seniors Responding Having Never Participated

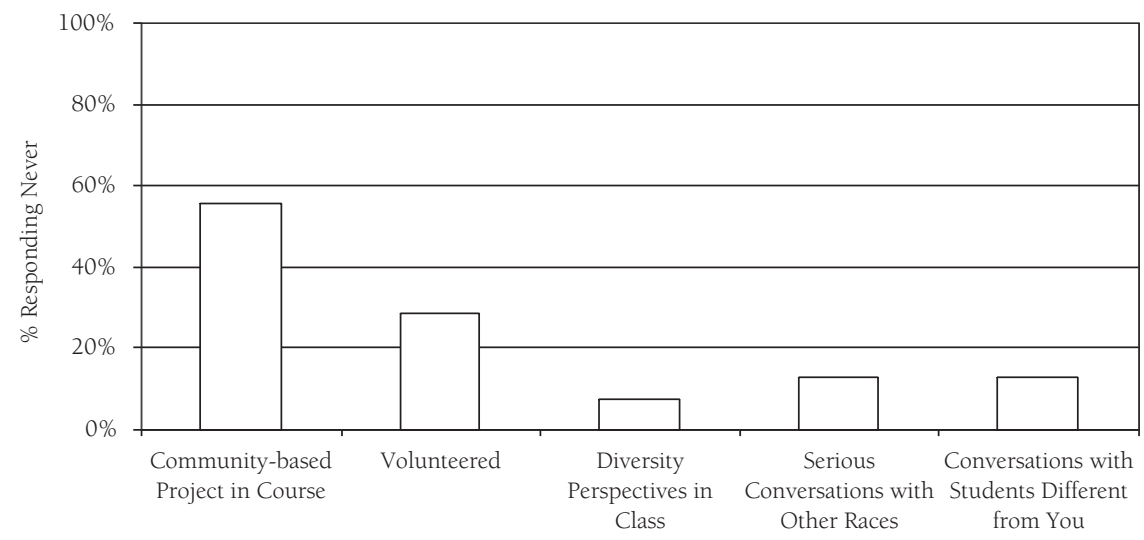

\section{Figure 4.3. NSSE 2002-03 Senior Reports of Contribution of College Experience}

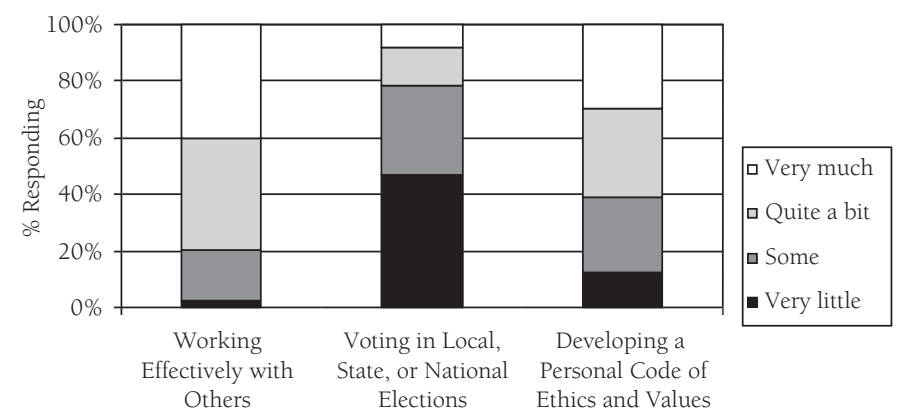

shows the average character development score (based on the arithmetic sum of responses to the items contributing to the four dimensions of character development described earlier) for five Carnegie types. As mentioned earlier, students at baccalaureate liberal arts colleges report making greater gains in character development, followed by their peers at baccalaureate general colleges; master's-granting institutions; and the two largest institutions, the doctoral/research university-extensive and doctoral/research university-intensive. The difference in the median scores between these institution types is not great, but the variation in character development gains within the respective types of institution is quite substantial, stretching more than two standard deviations for the middle 80 percent of scores on these measures. That is, although the average character development score is higher at a baccalaureate liberal arts college, nonetheless a substantial number of students score well below their average peers at doctoral/research university-extensives. Thus character development is not 


\section{Figure 4.4. Highest (left band) and Lowest (right band) Scoring NSSE 2002-03 Institutions on Self-Reported Character Development Gains}

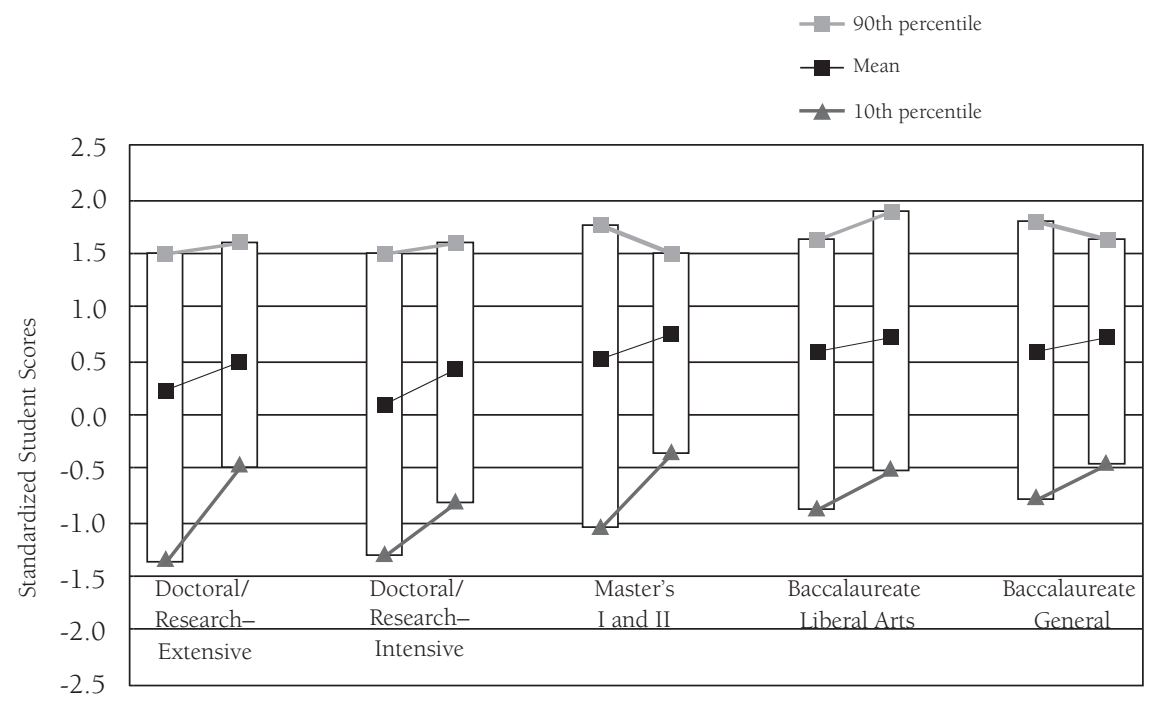

exclusively a function of small, residential, denominationally sponsored colleges.

Figure 4.4 shows this in starker relief, presenting the highest-scoring and lowest-scoring institutions from each category. The baccalaureate liberal arts college selected to represent the middle of its distribution has a relatively high average score, but a sizeable fraction of its students score much lower on the character development measure than the typical students at some other master's-granting institutions and even some large doctoral/ research-extensive universities. The highest-scoring master's institution has a relatively compressed range in terms of character development relative to many other institutions. Something significant may well be happening at this institution to produce such a pattern of findings.

Interestingly, those institutions that tend to score highest on character development attract students that are fairly homogeneous in terms of their background characteristics. They tend to be liberal arts colleges and a healthy proportion of general baccalaureate colleges. At the same time, students at these institutions tend to have more diversity-related experiences, even though these institutions generally have less structural diversity than larger public universities that enroll a larger number of ethnic minority students. Indeed, most of these institutions have relatively low structural diversity. We examined this phenomenon more closely in another study (Umbach and Kuh, 2003) and discovered that structural diversity was not the explanation for higher frequency of diversity-related experiences. Rather, something was 


\section{Figure 4.5. Self-Reported Gains in Character Development Score Among NSSE 2002-03 Seniors}

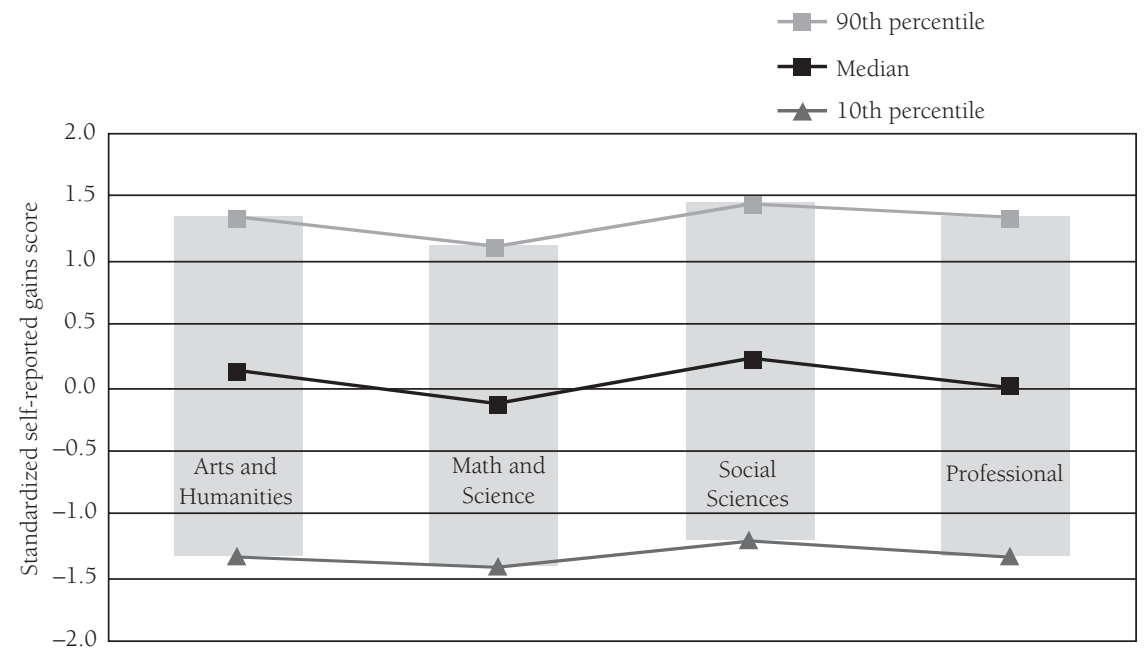

going on within these institutions that made it possible for students to interact more frequently with those (relatively few in number) members from other races and ethnicities who were present. It is also likely that the curriculum itself presented students with more opportunity to reflect on and deal with diverse perspectives.

As Figure 4.5 indicates, students in certain fields report a greater level of character development than others. Mildly surprising, perhaps, is that students in preprofessional fields such as health sciences and prelaw report gaining more in character development than their colleagues in the traditional arts and sciences fields.

\section{Multivariate Analysis}

The findings from our descriptive analyses suggest some important institutional and student differences in gains in character development. We explore this further in our multivariate analyses. Table 4.2 displays the student-level coefficients predicting character development and the character development subscales. Students of color report significantly greater gains than white students in character development. On every measure, African Americans, Native Americans, and Latinos indicate greater gains than whites. For three of the five measures, Asian Pacific Americans score higher than whites.

As suggested by our descriptive statistics, the level of gain in character development reported by students varies by major. Students in the social sciences report the highest gains in general character development, civic 
Table 4.2. Statistically Significant* Student-Level Coefficients (Represented in Effect Sizes)

\begin{tabular}{|c|c|c|c|c|c|}
\hline & $\begin{array}{c}\text { Character } \\
\text { Development }\end{array}$ & $\begin{array}{l}\text { Knowledge } \\
\text { of Self } \\
\text { and Others }\end{array}$ & $\begin{array}{l}\text { Ethical } \\
\text { Development } \\
\text { and Problem } \\
\text { Solving }\end{array}$ & $\begin{array}{c}\text { Civic } \\
\text { Responsibility }\end{array}$ & $\begin{array}{c}\text { General } \\
\text { Knowledge }\end{array}$ \\
\hline Gender & & 0.09 & & 0.06 & 0.08 \\
\hline Age & 0.01 & 0.00 & & 0.02 & 0.03 \\
\hline African American & 0.18 & 0.13 & 0.09 & 0.25 & 0.19 \\
\hline Native American & 0.28 & 0.21 & 0.20 & 0.26 & 0.26 \\
\hline Asian Pacific American & 0.02 & 0.14 & 0.07 & & -0.07 \\
\hline Latino & 0.21 & 0.19 & 0.17 & 0.17 & 0.19 \\
\hline \multicolumn{6}{|l|}{ Other minority } \\
\hline Major-humanities & -0.09 & & -0.13 & -0.17 & -0.02 \\
\hline Major-math and science & -0.20 & -0.16 & -0.08 & -0.33 & -0.16 \\
\hline Major-professional & -0.09 & 0.02 & -0.03 & -0.18 & -0.11 \\
\hline Major-other & -0.12 & -0.02 & -0.05 & -0.21 & -0.12 \\
\hline Greek & 0.12 & 0.08 & 0.10 & 0.15 & 0.08 \\
\hline Grades & 0.11 & 0.07 & 0.07 & 0.05 & 0.12 \\
\hline Full-time & 0.15 & 0.15 & 0.14 & 0.11 & 0.11 \\
\hline
\end{tabular}

*All coefficients presented are statistically significant, $p<.01$.

responsibility, and general knowledge. Math and science majors report the lowest gains on nearly every character development measure.

Table 4.3 presents the institution-level coefficients predicting gains in character development. In general, students at liberal arts colleges report greater gains in character development than students from other institution types. However, students at baccalaureate-general institutions report gains in knowledge of self and others, ethical development and problem solving, and civic responsibility that are not statistically significantly different from students at liberal arts colleges.

Although the effect sizes are somewhat modest, it seems that students at private colleges indicate greater gains in character development than students at public colleges. Additionally, institutional size is negatively related to reported gains in character development. As we expected, students at religiously affiliated institutions report greater gains in character development than students at unaffiliated institutions.

Table 4.4 displays the results from a fully controlled model (all institutional and individual controls) where each engagement, campus climate, and integrative measure is added to the model. Our findings suggest that engagement in effective educational practices generally enhances students' self-reported change in character development. Additionally, students at campuses that create a supportive campus climate and offer integrative experiences are more likely to indicate growth in character development. 
Table 4.3. Statistically Significant* Institution-Level Coefficients (Represented in Effect Sizes)

\begin{tabular}{|c|c|c|c|c|c|}
\hline & $\begin{array}{c}\text { Character } \\
\text { Development }\end{array}$ & $\begin{array}{l}\text { Knowledge } \\
\text { of Self } \\
\text { and Others }\end{array}$ & $\begin{array}{c}\text { Ethical } \\
\text { Development } \\
\text { and Problem } \\
\text { Solving }\end{array}$ & $\begin{array}{c}\text { Civic } \\
\text { Responsibility }\end{array}$ & $\begin{array}{l}\text { General } \\
\text { Knowledge }\end{array}$ \\
\hline \multicolumn{6}{|l|}{ Carnegie } \\
\hline $\begin{array}{l}\text { Research-Extensive } \\
\text { Doctoral/ }\end{array}$ & -0.25 & & -0.15 & -0.17 & -0.32 \\
\hline Research-Intensive & -0.30 & -0.14 & -0.18 & -0.20 & -0.35 \\
\hline Master's II and II & -0.16 & -0.07 & -0.10 & & -0.21 \\
\hline Baccalaureate general & -0.09 & -0.03 & -0.02 & 0.01 & -0.17 \\
\hline $\begin{array}{l}\text { Sector } \\
\text { Private }\end{array}$ & 0.14 & 0.07 & 0.13 & 0.09 & 0.14 \\
\hline \multicolumn{6}{|l|}{$\begin{array}{l}\text { Urbanicity } \\
\text { Suburban } \\
\text { Town/rural }\end{array}$} \\
\hline $\begin{array}{l}\text { Selectivity } \\
\text { Barron's }\end{array}$ & & -0.03 & & & 0.04 \\
\hline $\begin{array}{l}\text { Size } \\
\text { Undergrad head count }\end{array}$ & -0.06 & & -0.05 & -0.06 & -0.07 \\
\hline $\begin{array}{l}\text { Religiously affiliated } \\
\text { Affiliated }\end{array}$ & 0.19 & 0.10 & 0.18 & 0.20 & 0.15 \\
\hline
\end{tabular}

*All coefficients presented are statistically significant, $p<.01$.

\section{Limitations}

One limitation of this study is the measure of character development constructed from the NSSE survey. There are surely additional relevant dimensions of character that are not captured by these NSSE items. Another limitation is related to the validity of self-reported gains. As Pascarella (2001) and others point out, gain scores may be confounded by students' entering characteristics. Though Pike (1999) provides some evidence to suggest that gain scores are not significantly related to entering ability, it is likely that students who are committed to character development select a college that emphasizes character-promoting activities (such as community service).

Additionally, self-selection bias should be considered when interpreting the results. In the college choice process, students who seek to enhance their character may in fact be selecting particular colleges because they appear to foster an environment that would offer such opportunities. This possible self-selection may bias the relationship between religiously affiliated institutions and liberal arts colleges and the dependent measures of this study. 


\section{Table 4.4. Student-Level Coefficients (Represented in Effect Sizes)* of Engagement, Climate, and Integrative Experiences from Fully Controlled Model}

\begin{tabular}{lccccc}
\hline & $\begin{array}{c}\text { Character } \\
\text { Development }\end{array}$ & $\begin{array}{c}\text { Knowledge } \\
\text { of Self } \\
\text { and Others }\end{array}$ & $\begin{array}{c}\text { Ethical } \\
\text { Development } \\
\text { and Problem } \\
\text { Solving }\end{array}$ & $\begin{array}{c}\text { Civic } \\
\text { Responsibility }\end{array}$ & $\begin{array}{c}\text { General } \\
\text { Knowledge }\end{array}$ \\
\hline $\begin{array}{l}\text { Engagement } \\
\text { Academic challenge }\end{array}$ & 0.48 & 0.36 & 0.39 & 0.30 & 0.48 \\
Active and collaborative & 0.44 & 0.34 & 0.37 & 0.27 & 0.43 \\
Student-faculty interaction & 0.42 & 0.35 & 0.35 & 0.33 & 0.36 \\
Volunteering & 0.31 & 0.26 & 0.23 & 0.40 & 0.21 \\
Learning community & 0.32 & 0.30 & 0.28 & 0.35 & 0.22 \\
Supportive Campus Climate & & & & & \\
Supportive campus & 0.58 & 0.53 & 0.49 & 0.45 & 0.49 \\
$\quad$ Interpersonal support & 0.45 & 0.41 & 0.37 & 0.32 & 0.40 \\
$\quad$ Support for learning & 0.54 & 0.49 & 0.34 & 0.45 & 0.43 \\
Satisfaction & 0.53 & 0.46 & 0.42 & 0.30 & 0.48 \\
Integrative Experiences & & & & & \\
Integration & 0.48 & 0.39 & 0.40 & 0.34 & 0.45 \\
Diversity-related activities & 0.32 & 0.32 & 0.26 & 0.24 & 0.25 \\
\hline
\end{tabular}

*All coefficients presented are statistically significant, $p<.01$.

\section{Implications}

As with many other aspects of undergraduate education, colleges reap what they sow. Thus the mission, curriculum, and student's experiences must be aligned with character development as an intended outcome. If character development is important, institutions should both expect and require students to do the things that develop character. This would include those experiences that are connected to a greater level of character development, such as doing community service as part of a regular course and experiencing diversity. To do this successfully, awareness is a key first step; that is, students must actually know about opportunities to test and reflect on their values and beliefs in a way that induces them to integrate what they are learning with who they are becoming. Thus messages must be sent to students long before they arrive as to the value of developing a coherent constellation of values, ethics, and behavioral patterns that prepare them to live a civically responsible, socially aware, and economically productive life after college. Students must also be told early on, and then institutions must consistently reinforce the message, that opportunities will be presented for students to experience and integrate what they are learning from their courses with their social, political, and cultural lives. Then institutions must intentionally organize the students' in-class and out-of-class experiences so 
that they are exposed to the kind of activities and events that push them further along the character development path.

Given the variety of educational purposeful activities that are associated with character development, no one program is likely to have the desired effect on character development. That is, character cannot be "taught" in a single course, or developed as part of an orientation program or capstone experience. Rather, the multiple dimensions of character are cultivated through a variety of experiences that take place over an extended period of time in the company of others who are undergoing similar experiences. To this end, institutions should intentionally create opportunities for students inside and outside the classroom to integrate their experiences in a manner that nurtures character development. Indeed, it takes a whole campus to develop a student's character.

It is not surprising that smaller, religiously affiliated colleges appear to create an environment that is character-enhancing. To no small degree, character development is a focal point of the mission and culture of many of these institutions. Yet of the ten highest-scoring institutions on our global measure of character development, only two are unabashedly denominational; both are Catholic colleges, and several others are only nominally affiliated with a denomination. Three of the institutions are historically black colleges (one of which is public), and two others are among the more experimental and reformist in terms of their educational philosophy and pedagogical approach. Surprisingly, perhaps, four are single-sex colleges. It's not clear, then, what these schools have in common except that they tend to be small (eight of the ten schools have approximately two thousand students or less) and on average they all engage their students in value-driven activities that promote application and integration of classroom material to real-world issues.

Though we cannot speak in definitive terms about all the strongestperforming colleges on our measure of character development, we know enough about several of these institutions to say with confidence that they go well beyond simply offering opportunities for their students to reflect, refine, and test their values, ethics, and attitudes. That is, a campus can create a set of activities that theoretically should contribute to character development, but unless students actually experience or take part in those activities one cannot anticipate the desired effect. Institutions where students report making progress in development of character present a range of character-testing activities and require their students to take part in more than a few.

To know whether a school is actually achieving its character development purposes, a systematic assessment program is needed, one that provides feedback to close the loop and to guide and document initiatives that are designed for this effect. Systematic, ongoing assessment can help identify those students who do not participate in such activities and learn why. In addition, adjustments can and should be made to various programs to be sure they are having the desired effect on character development. The 
American Democracy Project of the American Association of State Colleges and Universities, sponsored by the New York Times, is one such effort to assess the impact of promoting civic engagement and student participation in allied activities inside and outside the classroom, with NSSE among other tools being used in the effort.

\section{Conclusion}

This study adds to our understanding of the college activities and institutional characteristics that are related to character development during the undergraduate years. As colleges and universities prepare students to conduct their lives in an ethically enlightened manner and in an increasingly diverse democracy, they would do well to stitch into their policies and practices activities that give students firsthand experience with issues that the larger society is grappling with through community involvement, service learning, and other assignments. Opportunities to interact across racial, religious, and socioeconomic lines also seem to be important to character development, as is a campus environment that emphasizes values-based curricular and co-curricular initiatives and induces student participation in these complementary activities.

\section{References}

Antonio, A. L. "Diversity and the Influence of Friendship Groups in College." Review of Higher Education, 2001, 25(1), 63-89.

Astin, A. W. Four Critical Years. San Francisco: Jossey-Bass, 1977.

Astin, A. W. What Matters in College: Four Critical Years Revisited. San Francisco: JosseyBass, 1993.

Astin, A. W., Sax, L. J., and Avalos, J. "Long-Term Effects of Volunteerism During the Undergraduate Years." Review of Higher Education, 1999, 22(2), 187-202.

Baird, L. L. "Biographical and Educational Correlates of Graduate and Professional School Admissions Test Scores." Educational and Psychological Measurement, 1976, 36(2), 415-420.

Barron's Educational Series. Profiles of American Colleges (25th ed.). Hauppage, N.Y.: Barron's, 2002.

Baxter Magolda, M. B. Making Their Own Way: Narratives for Transforming Higher Education to Promote Self-Development. Sterling, Va.: Stylus, 2001.

Berdie, R. F. "Self-Claimed and Tested Knowledge." Educational and Psychological Measurement, 1971, 31(3), 629-636.

Chang, M. J. "Does Racial Diversity Matter? The Educational Impact of a Racially Diverse Undergraduate Population." Journal of College Student Development, 1999, 40, $377-395$.

Chickering, A. W., and Gamson, Z. F. "Seven Principles for Good Practice in Undergraduate Education." AAHE Bulletin, 1987, 39(7), 3-7.

Chickering, A. W., and Reisser, L. Education and Identity (2nd ed.). San Francisco: Jossey-Bass, 1993.

Clark, B., and others. Students and Colleges: Interaction and Change. Berkeley: Center for Research and Development in Higher Education, University of California, 1972.

Feldman, K. A., and Newcomb, T. M. The Impact of College on Students. San Francisco: Jossey-Bass, 1969. 
Gurin, P. "Expert Report of Patricia Gurin.” In University of Michigan (ed.), The Compelling Need for Diversity in Higher Education, Gratz et al. v. Bollinger et al, no. 97-75231 (E.D. Mich.) and Grutter et al. v. Bollinger et al. no. 97-75928 (E.D. Mich.). Ann Arbor: University of Michigan, 1999.

Heath, D. H. Growing up in College: Liberal Education and Maturity. San Francisco: JosseyBass, 1968.

Horowitz, H. L. Campus Life: Undergraduate Cultures from the End of the Eighteenth Century to the Present. Chicago: University of Chicago Press, 1987.

Jacob, P. Changing Values in College: An Exploratory Study of the Impact of College Teaching. New York: HarperCollins, 1957.

Kuh, G. D. "Appraising the Character of College." Journal of Counseling and Development, 1993, 71(6), 661-668.

Kuh, G. D. "The Other Curriculum: Out-of-Class Experiences Associated with Student Learning and Personal Development." Journal of Higher Education, 1995, 66(2), $123-155$.

Kuh, G. D. "Assessing What Really Matters to Student Learning: Inside the National Survey of Student Engagement." Change, 2001, 33(3), 10-17, 66.

Kuh, G. D. "What We're Learning About Student Engagement from NSSE." Change, 2003, 35(2), 24-32.

Kuh, G. D., and Hu, S. "The Effects of Student-Faculty Interaction in the 1990s." Review of Higher Education, 2001, 24, 309-332.

McCormick, A. C. The Carnegie Classification of Institutions of Higher Education, 2000 Edition. Menlo Park, Calif.: Carnegie Foundation for the Advancement of Teaching, 2001.

Milem, J. F., and Hakuta, K. "The Benefits of Racial and Ethnic Diversity in Higher Education." In D. Wilds (ed.), Minorities in Higher Education: Seventeenth Annual Status Report. Washington, D.C.: American Council on Education, 2000.

National Survey of Student Engagement. From Promise to Progress: How Colleges and Universities Are Using Student Engagement Results to Improve Collegiate Quality. Bloomington: Center for Postsecondary Research, Indiana University, 2002.

National Survey of Student Engagement. Converting Data into Action: Expanding the Boundaries of Institutional Improvement. Bloomington: Center for Postsecondary Research, Indiana University, 2003.

Pace, C. R. The Credibility of Student Self-Reports. Los Angeles: Center for the Study of Evaluation, University of California, Los Angeles, 1985.

Parks, S. D. Big Questions, Worthy Dreams: Mentoring Young Adults and the Search for Meaning, Faith, and Commitment. San Francisco: Jossey-Bass, 2000.

Pascarella, E. T. "Using Student Self-Reported Gains to Estimate College Impact: A Cautionary Tale." Journal of College Student Development, 2001, 42(5), 488-492.

Pascarella, E. T., and Terenzini, P. T. How College Affects Students: Findings and Insights from Twenty Years of Research. San Francisco: Jossey-Bass, 1991.

Pike, G. R. "Limitations of Using Students' Self-Reports of Academic Development as Proxies for Traditional Achievement Measures." Paper presented at the annual meeting of the Association for Institutional Research, Boston, 1995.

Pike, G. R. "The Constant Error of the Halo in Educational Outcomes Research." Research in Higher Education, 1999, 40(1), 61-86.

Pike, G. R., and Kuh, G. D. "First- and Second-Generation College Students: A Comparison of Their Engagement and Intellectual Development." Journal of Higher Education, forthcoming.

Pike, G. R., Kuh, G. D., and Gonyea, R. M. "The Relationship Between Institutional Mission and Students' Involvement and Educational Outcomes." Research in Higher Education, 2003, 44, 241-261.

Pohlmann, J. T. "A Description of Effective College Teaching in Five Disciplines as Measured by Student Ratings." Research in Higher Education, 1974, 4(4), 335346. 
Raudenbush, S. W., and Bryk, A. A. Hierarchical Linear Models (2nd ed.). London: Sage, 2002.

Rosenthal, R., and Rosnow, R. L. Essentials of Behavioral Research: Methods and Data Analysis (2nd ed.). New York: McGraw-Hill, 1991.

Rudolph, F. The American College and University: A History. Athens: University of Georgia Press, 1990.

Sanford, N. "The Developmental Status of the Freshman." In N. Sanford (ed.), The American College: A Psychological and Social Interpretation of the Higher Learning. New York: Wiley, 1962.

Umbach, P., and Kuh, G. D. "Student Experiences with Diversity at Liberal Arts Colleges: Another Claim for Distinctiveness." Paper presented at the annual meeting of the Association for Institutional Research, Tampa, 2003.

GEORGE D. KUH is chancellor's professor of higher education and director of the Center for Postsecondary Research at Indiana University. His research interests include assessing student and institutional performance to improve the quality of the undergraduate experience.

PAUL D. UMBACH is assistant professor in the Department of Educational Policy and Leadership Studies, University of Iowa. His research examines the impact of organizations and social structures on student outcomes and the careers of faculty and senior administrators. 
Copyright of New Directions for Institutional Research is the property of Jossey-Bass, A Registered Trademark of Wiley Periodicals, Inc., A Wiley Company and its content may not be copied or emailed to multiple sites or posted to a listserv without the copyright holder's express written permission. However, users may print, download, or email articles for individual use. 